\title{
Aspergillus Flavus Complex
}

National Cancer Institute

\section{Source}

National Cancer Institute. Aspergillus Flavus Complex. NCI Thesaurus. Code C122244.

A non-taxanomic grouping of bacteria that have been assigned to the Aspergillus genus

and are morphologically and physiologically similar to Aspergillus flavus. 